\section{Resources available to prepare for WHCLIS}

\author{
by Patricia A. Wand
}

Chair, ACRL Task Force on WHCLIS

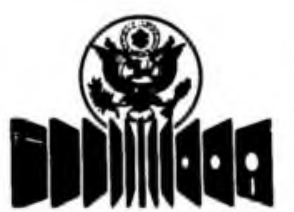

THE WHITE HOUSE CONFERENCE ON
LibRARY AND INFORMATION SERVICES
1991
Academic librarians are among the 750 who have been selected to serve as delegates to the White House Conference on Library and Information Services. Besides the fourteen academic librarian delegates cited in the March 1991 issue of C\&RL News, eight more have notified this author of their selection:

Delaware: Carolyn Davis (Delaware Community and Technical College)

Ohio: Judith A. Sessions (Miami University)

Oklahoma: Edward Johnson (Oklahoma State University)

Pennsylvania: E. J. Josey (University of Pittsburgh) and Charles Peguese (Harrisburg Area Community College)

Rhode Island: Robert Schnare (U.S. Naval War College)

South Dakota: Leon Raney(South Dakota State University)

Texas: Mary L. Nieball (San Jacinto College)

A special program aimed at academic librarian delegates is scheduled for the final portion of the ACRL Presidents Program during the ALA Annual Conference in Atlanta. All delegates and interested ACRL members are invited to attend on Monday, July 1, 1991, 2-4:30 p.m.

Delegates to the second White House Conference on Library and Information Services (WHCLIS) face a challenge known to all professionals: an abundance of information and a finite amount of time in which to assimilate it. Resolutions and recommendations from 59 state, territory, and special-interest group pre-Conference events are arriving in the WHCLIS Office. Various individuals and groups have written position papers providing background information for delegates and concerned legislators.

To synthesize information into manageable packages, WHCLIS staff are publishing several documents, including Discussion Papers and Issues Briefing Book. Discussion Papers, a 15-page book- let, comprises three papers underscoring the umbrella themes of the White House Conference: democracy, literacy, and productivity. In "The Library in Service to Democracy," Timothy S. Healy, president, The New York Public Library, links libraries with freedom's many meanings and reminds the reader of the role of libraries in the historical development of democracy in the United States:

"Under any republican form of government, where knowledge and understanding must be attributed to individuals as citizens and voters, the service rendered by libraries is as necessary as that of the press, the colleges or the schools. Libraries exist essentially in service to freedom."

Patricia Senn Breivik, associate vice-president for Information Resources, Towson State University, Maryland, expands the concept of illiteracy in her essay "Literacy in an Information Society." She notes the growing awareness that "literacy can no longer be considered merely the ability to read and memorize a base of knowledge; instead, it must become the ability to acquire and evaluate whatever information is needed at any given moment." She calls information literacy the next logical step to combat illiteracy and challenges WCHLIS delegates to issue a call for educational leaders "to address questions of information access and information literacy for all levels of today's students."

In his paper "Productivity in the Information Society," Paul E. Shay, futurist and consultant in Silicon Valley, California, defines productivity as "the application of information to an economic process or activity." He discusses future trends that affect libraries and information services. In contrast to blue collar and white collar workers of the industrial age, Shay calls information specialists the gold collar workers in the information age and predicts they will make a difference on "the bottom line." The importance of the White House Conference is underscored by his position: "Information is the new strategic resource, replacing land, labor and capital. A sophisticated information infrastruc- 
ture is the foundation upon which the new growth industries can be built."

Issues Briefing Book was written in April 1991 by ten Topics Committees brought together in Washington, D.C., for the express purpose of defining and explaining ten topics that have been most often named during the pre-WHCLIS activities. The topics are: access, networking, technologies, personnel, national information policies, preservation, training of end users, marketing, services/programs, and governance.

Topics Committee members consolidated 1,100 recommendations received from state and terri- tory pre-WCHLIS events into 150 suggested solutions. The recommendations are preserved and indexed by their originating state or territory. Issues Briefing Book will be published in early June and will be distributed to delegates before the White House Conference.

Copies of Discussion Papers and Issues Briefing Book may be requested from the office of the White House Conference on Library and Information Services, 1991, 1111 8th Street, N.W., Suite 302, Washington DC 20036, Telephone (202) 2545100 .

(Washington Hotline con't from page 377)

On April 8, ALA and ARL jointly submitted specific legislative amendments and rationale to the House subcommittee as requested by its chair and ranking minority member. Recommendations were based on the work of the ACRL Government Relations Committee. The American Council on Education and 11 other higher education associations endorsed the ALA/ARL recommendations for HEA II.

The recommendations proposed: reauthorization of HEA Title II with a new name, "Academic Libraries in an Electronic Networked Environment," to reflect the changing roles of libraries and librarians in response to new ways of providing information; deletion of the current II-A grants for college library resources (unfunded since FY 1983) and replacement with an updated II-D technology assistance program; and continuation with minor amendments of the IIB program of research and education and the II-C grants to major research libraries.

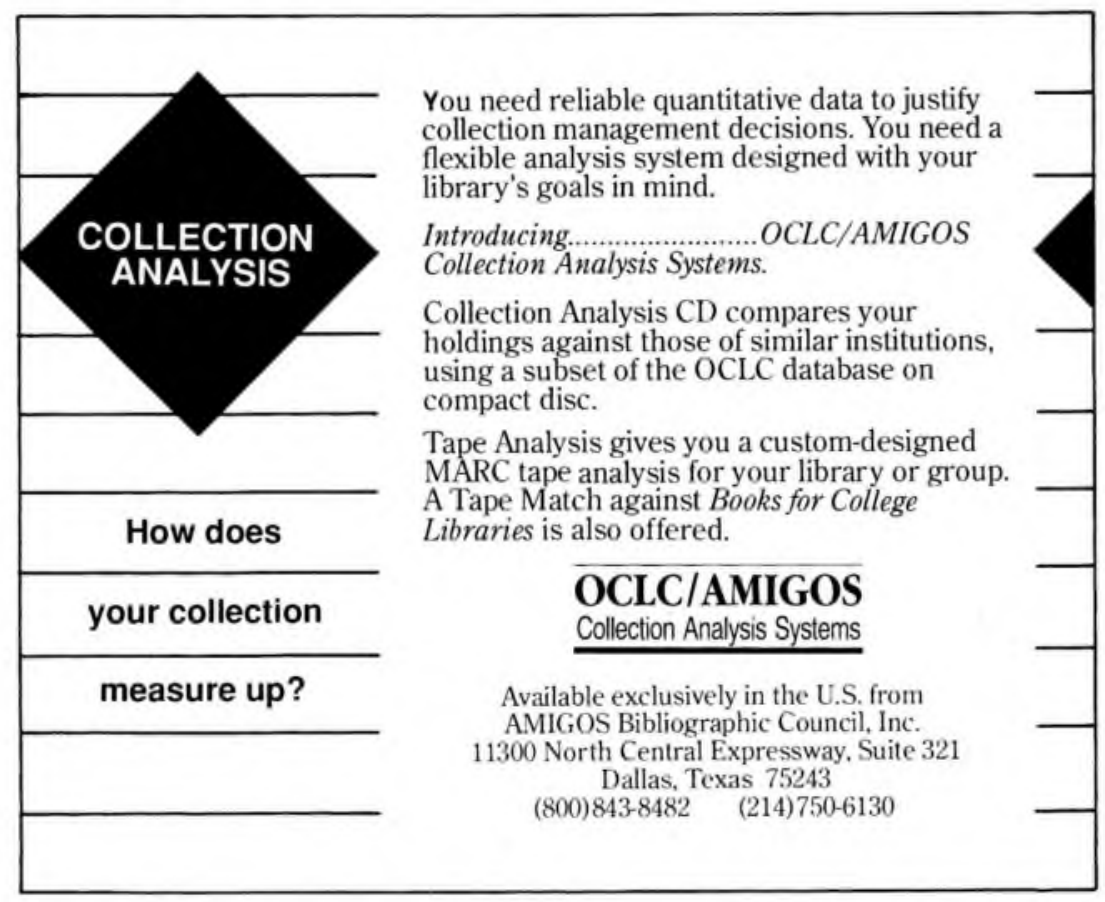

